
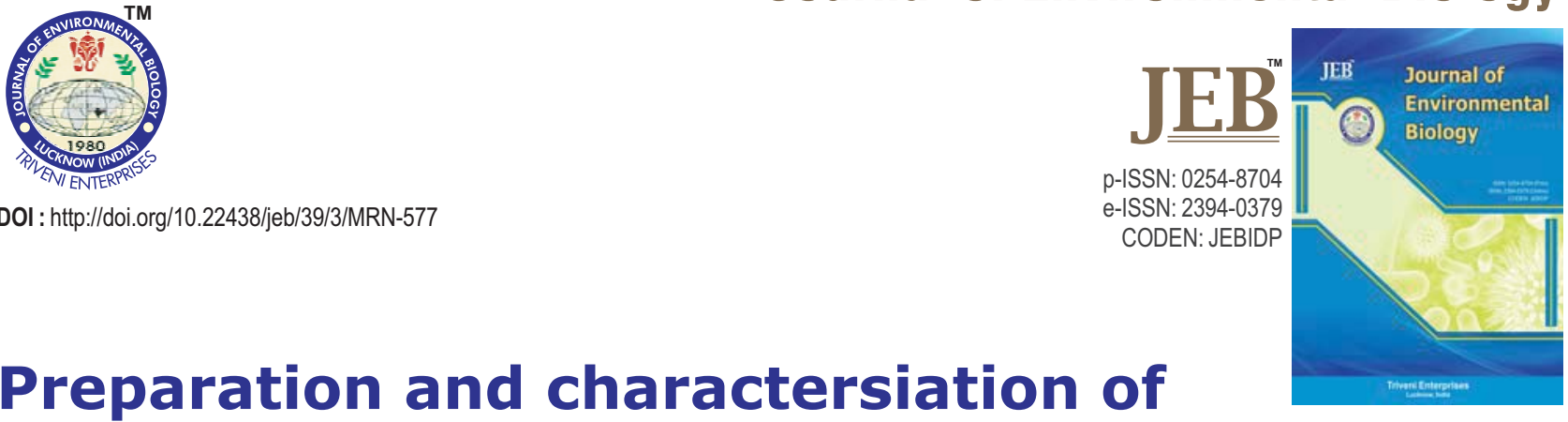

\title{
Preparation and charactersiation of low cost adsorbent from groundnut foliage by chemical activation
}

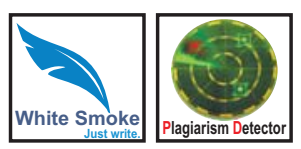

Authors Info

D. Vidhya Lakshmi, L. Anitha Jegadeeshwari, N. Arunodhaya, E. Vasanth Kumar and N. Nagendra Gandhi*

Department of Chemical Engineering, AC Tech Campus, Anna University, Chennai-600 025, India

*Corresponding Author Email : nagendragandhi.n@gmail.com

Key words

Activated carbon

Agro based waste

Groundnut foliage

Isotherms

Low cost adsorbent

\section{Publication Info}

Paper received : 02.02.2017

Revised received : 24.06 .2017

Re-revised received: 02.09.2017

Accepted: 13.09.2017

\section{Abstract}

Aim : Effective treatment and management of wastewater and solid waste are the major challenges growing at an alarming rate in today's world. The aim of the present study was to find the feasibility of utilizing agro-based waste (groundnut foliage) as a low cost adsorbent for dye laden waste water treatment.

Methodology : Groundnut foliage was collected from different villages in Villupuram district, Tamil nadu and was converted into an activated carbon by chemical activation method. Activation was done with different activating conditions (activating agents, impregnation ratio and activation temperature). Methylene blue number and lodine number for prepared activated carbon was determined using standard procedure. The optimized activation condition for groundnut foliage activated carbon was selected based on the yield (\%), Methylene blue number and lodine number. Batch adsorption studies were done using methylene blue as adsorbate to find the effects of adsorption parameters. Adsorption isotherm models like Langmuir and Freundlich were used to analyse the suitability of equilibrium data.

Results : Activated carbon was prepared using concentrated $\mathrm{H}_{3} \mathrm{PO}_{4}$ as activating agent with ratio of $1: 2$ at $600^{\circ} \mathrm{C}$ has better percentage of yield (> 45\%), Methylene blue value $\left(27 \mathrm{mg} \mathrm{g}^{-1}\right)$ and lodine value (1143 $\mathrm{mg} \mathrm{g}^{-1}$ ) when compared with activated carbon prepared using $\mathrm{ZnCl}_{2}$ and
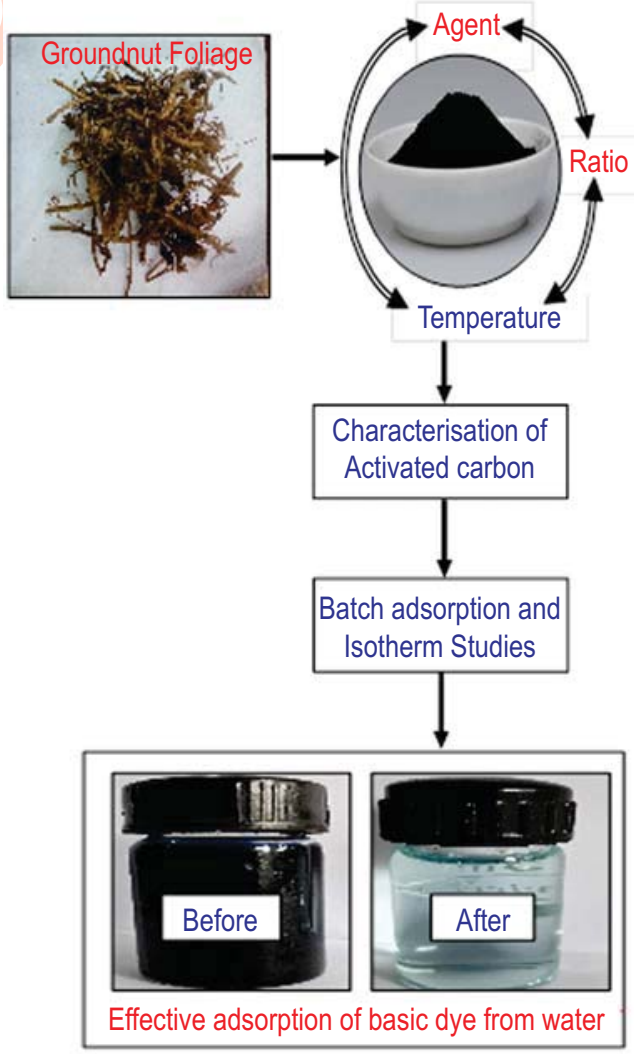
$\mathrm{KOH}$ as activating agent. For $100 \mathrm{mg} \mathrm{I}^{-1}$ of methylene blue dye concentration and at $6 \mathrm{pH}$ in $30^{\circ} \mathrm{C}$, about $89 \%$ of methylene blue dye removal was adsorbed with $0.25 \mathrm{~g}$ of groundnut foliage activated carbon. Adsorption followed the Langmuir model.

Interpretation : Low cost adsorbent prepared using groundnut foliage (agro-based waste) has desired properties of adsorbent and can be effectively used in dye laden waste water treatment. 


\section{Introduction}

Environmental pollution is the most alarming problem with the current world scenario. Water pollution due to discharge of effluents into the water bodies is a complex issue. Major industries like textile, leather and plastic industry discharges voluminous dye-laden wastewater into water bodies. Around $1,00,000$ commercially available dyes with over $7 \times 10^{5}$ tonnes of dyestuff produced annually (Tan et al.,2007) and about $10-15 \%$ of dye used will be discharged in the effluent (Cherifi et al.,2013). Since dyes are non-biodegradable in nature, many techniques like chemical coagulation/flocculation, chemical precipitation, adsorption, electrocoagulation, ozonation, oxidation, ion exchange, reverse osmosis, and ultra-filtration have been widely used to remove dyes from effluents for complying stringent legislation (Benadjemia et al., 2011; Ismaiel et al., 2013; Roopavathi and Shanthakumar, 2016). Among the different techniques, adsorption is considered to be more efficient, economical, flexible and simple physico chemical technique for treatment of dye-loaded wastewater (Amuda et al., 2014). Commercial adsorbents like activated carbon, zeolites, silica gel, activated alumina and polymeric adsorbents (Alau et al., 2010) were used for removing various range of pollutants.

Activated carbons are mostly used adsorbent because of their extremely high surface areas, micropore volumes, significant adsorption capacities, fast adsorption kinetics and easy regeneration (Prahas et al., 2008). The choice of activated carbon precursor depends on carbon content, accessibility, cost, purity preparation process and intended product application (Bahri et al., 2012). Commercial adsorbents are still considered to be an expensive option (lyer et al., 2016). Utilization of agricultural wastes for activated carbon preparation is a promising alternative to solve environmental problems and also to reduce the cost of commercial activated carbon (Dias et al., 2007). Reasons for considering agricultural residues or byproducts for activated carbon preparation are it is renewable nature and profuse availability (Prahas et al., 2008).

Many agro-wastes such as stems (Hescel and Klose, 1995), stalks (Tsai et al., 1997), straws (Corcho-corral et al., 2006) and hulls (Ozer et al., 2007; Wang et al., 2008; Belaid et al., 2013) were investigated for activated carbon preparation. Studies on groundnut shell or husk (Malik, 2004; Malik, 2006; Belaid et al., 2013) is available whereas for groundnut foliage there is no literature available. Hence, in this paper utilization of agricultural residue groundnut foliage as activated carbon precursor is being reported by considering its ample availability irrespective of season. India ranks second in groundnut production and conversion of groundnut foliage into activated carbon will be cost effective when compared with commercial activated carbon.

The objective of the present study was to attain the optimum activating conditions (activating agent, impregnation ratio and activation temperature) for preparing activated carbon from groundnut foliage by chemical activation method. Prepared groundnut foliage activated carbon were characterized based on their yield, Methylene blue number and iodine number. Batch adsorption study was conducted with methylene blue dye as adsorbate to find the effects of adsorption parameters.

\section{Materials and Methods}

Preparation of activated carbon : Groundnut foliage was collected from nearby agricultural field, washed several times to remove silt. Proximate analysis of groundnut foliage (\%, dry basis) had moisture content (13.5\%), volatile matter $(27.89 \%)$, ash content (11.5\%) and fixed carbon (47.11\%). Washed groundnut foliage was sun-dried for a week and oven dried at $75^{\circ} \mathrm{C} \pm 5^{\circ} \mathrm{C}$ for overnight. Dried groundnut foliage was shredded into small pieces for ease impregnation. Groundnut foliage activated carbon were prepared by chemical activation method using different activating agents $\left(\mathrm{KOH}, \mathrm{ZnCl}_{2}\right.$ and Concentrated $\mathrm{H}_{3} \mathrm{PO}_{4}$ ). Weight ratio used for impregnation was 1:1, 1:2 and 1:3 (weight of precursor : weight of activating agent). Samples were impregnated in respective aqueous solutions for $24 \mathrm{hrs}$ and then activated for $1 \mathrm{hr}$ at temperature ranging from 500 to $700^{\circ} \mathrm{C}$ in muffle furnace. After activation, resultant groundnut foliage activated carbon was repeatedly washed with distilled water (till rinse water $\mathrm{pH}$ becomes neutral), dried in oven at $110^{\circ} \pm 5^{\circ} \mathrm{C}$ (till constant weight), grounded and stored in air tight containers for further use.

Characterization of groundnut foliage activated carbon : Yield (\%) is a vital parameter in activated carbon preparation and was calculated by ratio of weight of activated carbon to the weight of groundnut foliage multiplied by 100 .

Methylene blue number reveals adsorption capacity of an adsorbing molecules, whereas iodine number provides the details of quality of groundnut foliage activated carbon prepared. Standard methods of BIS (1997) and ASTM (2006) were used to find methylene blue number and iodine number, repectively.

The batch adsorption experiments were conducted with fixed weight of optimized groundnut foliage activated carbon $(0.25 \mathrm{~g}$ per $100 \mathrm{ml})$ and volume of methylene blue solutions (100 $\mathrm{ml})$. The effect of contact time (0-360 min), initial dye concentration (50-300 $\mathrm{mg} \mathrm{I}^{-1}$ ) and solution $\mathrm{pH}(2.0-10)$ were studied at $30^{\circ} \mathrm{C}$ by stirring the flasks in a temperature controlled shaker (Orbital, Scigenics) at $150 \mathrm{rpm}$. The $\mathrm{pH}$ of the solutions was adjusted using $0.1 \mathrm{M} \mathrm{HCl}$ or $\mathrm{NaOH}$. The dye concentrations at a prescribed interval were analyzed using a double beam UV-Vis spectrophotometer (Elico SL210 Model) at $665 \mathrm{~nm}$. Prior to analysis, samples were filtered to minimize interference of activated carbon during analysis. The adsorption capacity (q.) was calculated. Equilibrium studies were done with fixed weight of optimized groundnut foliage activated carbon $(0.25 \mathrm{~g})$ and volume of methylene blue solution $(100 \mathrm{ml})$ at varying concentrations $\left(50-300 \mathrm{mg} \mathrm{l}^{-1}\right)$. The flasks were allowed to attain 
equilibrium by agitating in $150 \mathrm{rpm}$ for $24 \mathrm{hrs}$ at $30^{\circ} \mathrm{C}$. The samples were then filtered, analyzed using a double beam UV-Vis spectrophotometer (Elico SL210 Model) at $665 \mathrm{~nm}$ and equilibrium adsorption capacity $\left(q_{\mathrm{e}}\right)$ of groundnut foliage activated carbon was calculated.

\section{Results and Discussion}

It is evident that use of $\mathrm{ZnCl}_{2}$ and $\mathrm{H}_{3} \mathrm{PO}_{4}$ as activating agent yields a higher percentage of activated carbon (Table 1). Also, the impregnation ratio and temperature has significant effect on the yield. Higher yield was observed in $1: 2$ ratio at $600^{\circ} \mathrm{C}$ for $\mathrm{ZnCl}_{2}$ and $\mathrm{H}_{3} \mathrm{PO}_{4}$. Yield obtained in the activated carbon prepared using $\mathrm{KOH}$ was low when compared to other two agents. $\mathrm{KOH}$ being the strong base catalyse the reaction resulting in low yield of activated carbon (Sudaryanto et al., 2006). Activated carbon having iodine number greater than $900 \mathrm{mg} \mathrm{g}^{-1}$ possess high surface area (Benadjemia et al., 2011) and are suitable for adsorbing small compounds (Bestani et al., 2008). $\mathrm{H}_{3} \mathrm{PO}_{4}$ has been widely used in studies as activating agent because of its tendency to create palpable surface area and better yield which was also confirmed in the study. $\mathrm{ZnCl}_{2}$ as an activating agent also showed similar yield, however due to environmental degradation caused on recovering the agent makes it unfit for sensitive systems like food and pharmaceutical industry. Hence, $\mathrm{H}_{3} \mathrm{PO}_{4}$ has better applicability in preparation of activated carbon compared to $\mathrm{ZnCl}_{2}$.

Activation temperature is a significant parameter which influences the properties of the prepared groundnut foliage activated carbon. Activation temperature must convert the cellulose and hemicellulose constituents of groundnut foliage into activated carbon. Decomposition of hemicellulose and cellulose occur in the temperature range of $180^{\circ}-240^{\circ} \mathrm{C}$ and $230^{\circ}-310^{\circ} \mathrm{C}$, respectively (Zeriouh and Belkbir, 1995) Fig. 1 a-c and 2 a-c, but decomposition of lignin is slow and has a wide temperature range between $150^{\circ}-750^{\circ} \mathrm{C}$ (Tsamba et al., 2006). Hence, temeperature range of of $500^{\circ}-700^{\circ} \mathrm{C}$ was selected to determine the effect of temperature on groundnut foliage activated carbon activation. Table 1, Fig. $1(\mathrm{a}-\mathrm{c})$ and $2(\mathrm{a}-\mathrm{c})$ shows the effects of temperature on yield, methylene blue number and iodine number on prepared activated carbon. Yields decreased with increase in activation temperature due to the removal of volatile matter. Decomposition of organics create the internal surface area. Methylene blue number and iodine value indicate the micropore and mesopore developed in groundnut foliage activated carbon during activation process. Based on yield, methylene blue number and iodine number, $600^{\circ} \mathrm{C}$ was chosen as optimum activation temperature for groundnut foliage activated carbon.

The influence of impregnation ratio of different activating agents on groundnut foliage activated carbon was examined with three different ratios (1:1,1:2 and 1:3). The results of groundnut foliage impregnated with $\mathrm{KOH}, \mathrm{ZnCl}_{2}$ and $\mathrm{H}_{3} \mathrm{PO}_{4}$ in the desired ratio are depicted in Fig. $1(\mathrm{a}-\mathrm{c})$ and $2(\mathrm{a}-\mathrm{c})$. From the Methylene blue number and iodine number, it is evident that $\mathrm{ZnCl}_{2}$ and $\mathrm{H}_{3} \mathrm{PO}_{4}$ showed significant effect on groundnut foliage activated carbon. use of $\mathrm{ZnCl}_{2}$ and $\mathrm{H}_{3} \mathrm{PO}_{4}$ in activated carbon preparation, when cellulosic precursor was used, prevents accumulation of tar on the carbon surface and provides further decomposition and develops microporosity (Ozdemir et al., 2014; Rodriguez-Reino and Molina-Sabio, 1992). Methylene blue value for activated carbon prepared using $\mathrm{ZnCl}_{2}$ and $\mathrm{H}_{3} \mathrm{PO}_{4}$ as activating agents have considerable variation from 18 to $36 \mathrm{mg} \mathrm{g}^{-1}$. With the change in ratio, minimum of $100 \mathrm{mg} \mathrm{g}^{-1}$ change in iodine number was observed for all temperature range studied. On comparing the performance of $\mathrm{ZnCl}_{2}$ and $\mathrm{H}_{3} \mathrm{PO}_{4}$, based on the yield, methylene blue number and iodine number, $\mathrm{H}_{3} \mathrm{PO}_{4}$ activated groundnut foliage showed better result. The order of performance of the selected activating agents was found in the following order: $\mathrm{H}_{3} \mathrm{PO}_{4}>\mathrm{ZnCl}_{2}>\mathrm{KOH}$. Groundnut foliage activated carbon prepared using concentrated $\mathrm{H}_{3} \mathrm{PO}_{4}$ agent with ratio of $1: 2$ at $600^{\circ} \mathrm{C}$ showed better yield, methylene blue number $\left(27 \mathrm{mg} \mathrm{g}^{-1}\right)$ while iodine number (1143 $\mathrm{mg} \mathrm{g}^{-1}$ ) had optium results, hence it was selected for adsorption and isotherm studies.

Removal of methylene blue dye on groundnut foliage activated carbon and influencing parameters like time and initial dye concentration were also studied. The initial concentration of methylene blue between 50 to $300 \mathrm{mg} \mathrm{g}^{-1}$ reached equilibrium between 240 to $360 \mathrm{~min}$. Higher the dye concentration longer the time taken to achieve equilibrium. Maximum removal percentage of methylene blue dye was found to be $85 \%$ for $100 \mathrm{mg} \mathrm{l}^{-1}$ dye concentration. Effect of $\mathrm{pH}$ was assessed by varying the $\mathrm{pH}$ between 2 to 10 using $\mathrm{HCl}$ and $\mathrm{NaOH}$ solutions in $100 \mathrm{mg} \mathrm{l}^{-1}$ of initial methylene blue dye concentration with $0.25 \mathrm{~g}$ of groundnut foliage activated carbon and the solution was equilibrated to 240

Table 1 : Yield percentage of prepared groundnut foliage activated carbon at different activating conditions

\begin{tabular}{|c|c|c|c|c|c|c|c|c|c|}
\hline \multirow{3}{*}{$\begin{array}{l}\mathrm{T} \\
\left({ }^{\circ} \mathrm{C}\right)\end{array}$} & \multicolumn{9}{|c|}{ Yield (\%) } \\
\hline & \multicolumn{3}{|c|}{$\mathrm{KOH}$} & \multicolumn{3}{|c|}{$\mathrm{ZnCl}_{2}$} & \multicolumn{3}{|c|}{$\mathrm{H}_{3} \mathrm{PO}_{4}$} \\
\hline & 1 & 2 & 3 & 1 & 2 & 3 & 1 & 2 & 3 \\
\hline 500 & 27 & 26 & 23 & 52.6 & 61.3 & 59 & 52.6 & 58.6 & 52 \\
\hline 600 & 26 & 25 & 22 & 50.6 & 58.6 & 58.6 & 51.8 & 58 & 51 \\
\hline 700 & 21 & 23 & 20 & 48 & 56 & 56 & 50.5 & 57.6 & 50 \\
\hline
\end{tabular}



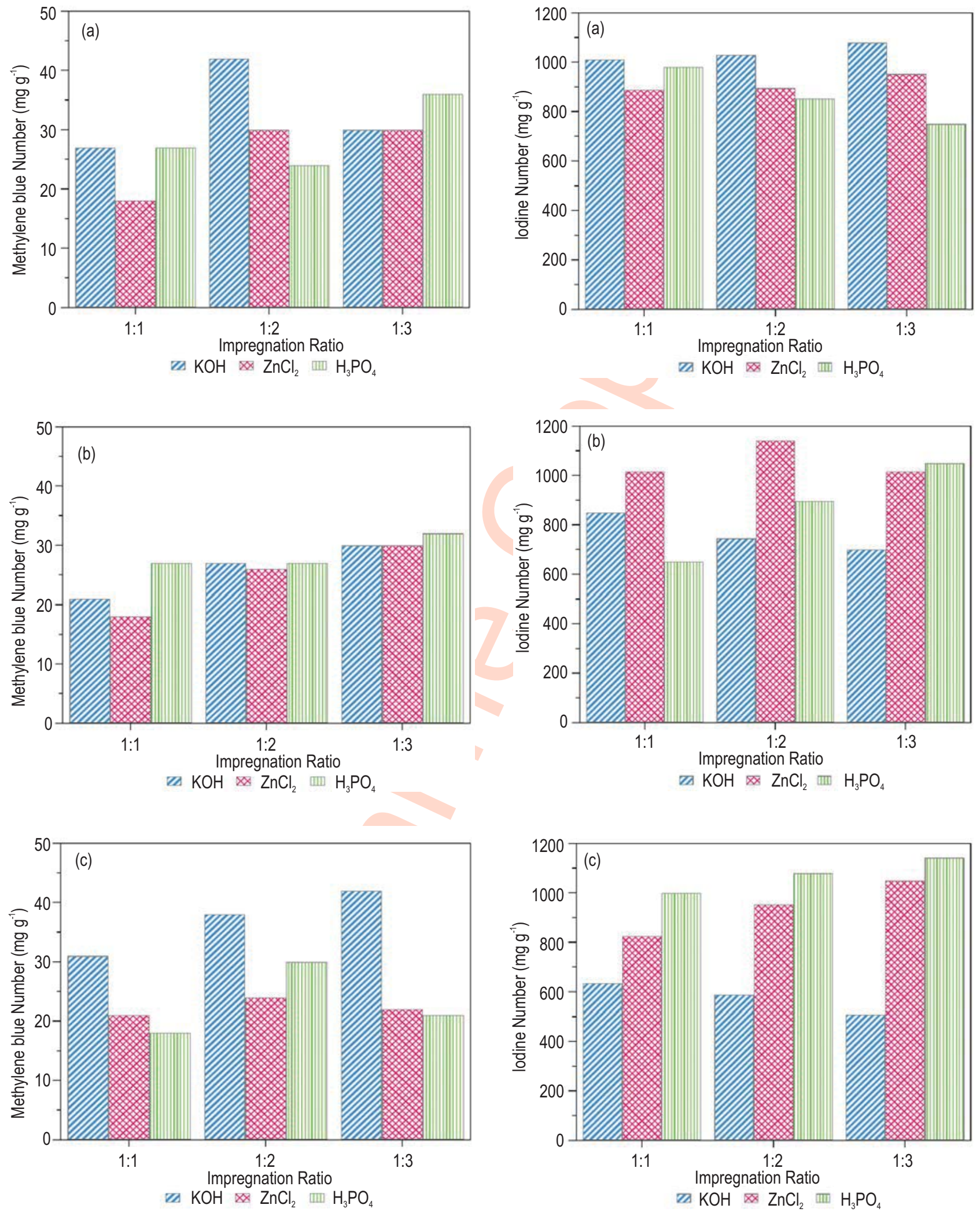

Fig. 1 : Methylene blue number of groundnut foliage activated carbon with differentactivating conditions: (a) $500^{\circ} \mathrm{C}$; (b) $600^{\circ} \mathrm{C}$ and (c) $700^{\circ} \mathrm{C}$

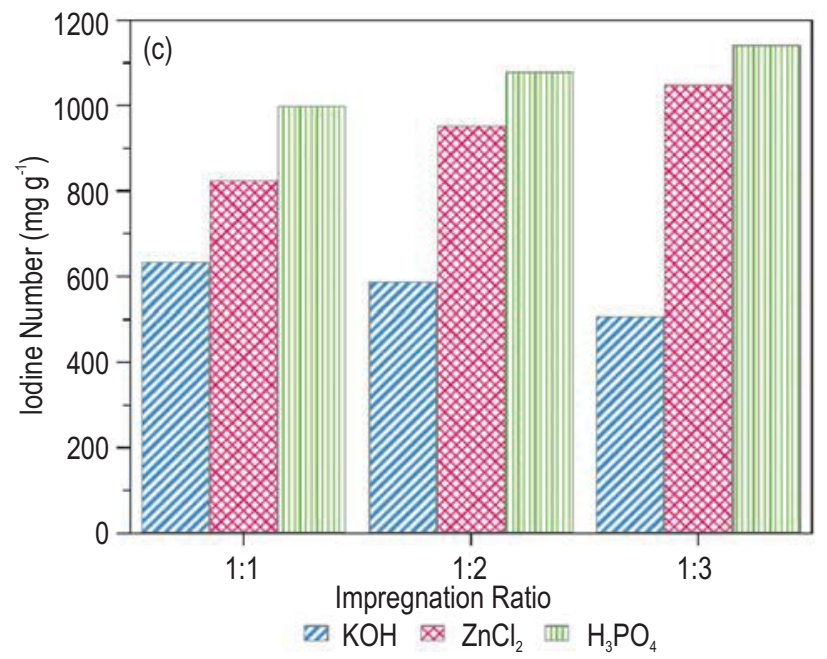

Fig . 2 : lodine number of of groundnut foliage activated carbon with different activating conditions : (a) $500^{\circ} \mathrm{C}$; (b) $600^{\circ} \mathrm{C}$ and (c) $700^{\circ} \mathrm{C}$ 
min. It was noted that $\mathrm{pH}$ below acidic and above alkaline range showed less methylene blue removal $(<80 \%)$, whereas at $\mathrm{pH} 6$, maximum of $89 \%$ removal was achieved. Similarly adsorption of methylene blue on garlic peel (Hameed and Ahmad, 2009) and corn cob (Reddy et al., 2016) has no effect on removal percentage of dye beyond the $\mathrm{pH}$ of 6 , due to change in the surface charge of the adsorbent.

Adsorption Isotherm : Adsorption isotherm is basically important to define solute interaction with adsorbents and is critical in optimizing the use of adsorbents (Tan et al., 2007). Langmuir and Freundlich isotherm is most widely used isotherms for adsorption process and its applicability can be carried out by comparing the correlation coefficient $\left(R^{2}\right)$. Langmuir isotherm assumes monolayer adsorption onto a surface containing a finite number of adsorption sites and Freundlich isotherm model assumes heterogeneous surface energies, wherein the energy term of Langmuir equation changes as a function of surface coverage (Hameed et al., 2007).

The plot of $C_{e} / q_{e}$ versus $C_{e}$ should be a straight line with $1 / X_{m}$ as slope and $1 /\left(X_{m} b\right)$ as intercept. The respective values of $X_{m}, b$ and $R^{2}$ were $93.458,0.003$ and 0.9908 . The separation factor or equilibrium parameter $\left(R_{L}\right)$ is dimensionless constant, which indicates the shape of the isotherm based on the value of $R_{L}$ (irreversible $\left(R_{L}=0\right)$, linear $\left(R_{L}=1\right)$, favorable $\left(0<R_{L}<1\right)$, and unfavorable $\left(R_{L}>1\right)$ ) (Malik, 2004). The value of $R_{L}$ in the present study was found to be 0.3 and this confirms that the prepared activated carbon is favorable for adsorption of dye laden wastewater treatment.

The Freundlich isotherm can be used for non-ideal sorption that involves heterogeneous surface energy systems. The significance of the exponent (1/n) gives an indication of adsorption favorability and if the value of $n>1$ denotes favorable adsorption condition (Malik, 2004). A plot of $\log$ qe versus $\log C_{e}$ will give a straight line with slope $(1 / n)$ and intercept $\left(K_{F}\right)$. From the plot, adsorption capacity and adsorption intensity was found to be 28.56 $\mathrm{mg} \mathrm{g}^{-1}$ and $3.278 \mathrm{Lg}^{-1}$. Also, the $\mathrm{R}^{2}$ was found to be 0.988 which was slightly less than the Langmuir isotherm. Both the isotherm responded well for the system, but it fitted best in Langmuir isotherm $\left(R^{2}=0.9908\right)$, which implies that adsorption was monolayer. Similar results were reported by (Reddy et al., 2016; Hameed et al., 2007; Kannan and Sundaram, 2001). It can be concluded that groundnut foliage activated carbon possesses similar characteristics of commercially available activated carbon to an larger extent and hence can be considered using as effective low cost adsorbent material for treating water contaminated with dye.

\section{References}

Alau, K. K., C. E. Gimba, J. A. Kagbu and B. Y. Nale: Preparation of activated carbon from neem (Azadirachta indica) husk by chemical activation with $\mathrm{H}_{3} \mathrm{PO}_{4}, \mathrm{KOH}$ and $\mathrm{ZnCl}_{2}$. Arch. Appl. Sci. Res., 2, 451-55(2010).
Amuda, O.S., A.O. Olayiwola, A.G. Farombi and S.A. Adebisi: Adsorption of methylene blue from aqueous aolution using steam-activated carbon produced from Lantana camara stem. J. Environ. Prot., 5, 1352-1363 (2014).

ASTM : Standard test method for determination of iodine number of activated carbon, ASTM Committee on Standards, ASTM D 460794, ASTM, Philadelphia, PA, USA(2006).

Bahri, M. Al., L. Calvo, M. A. Gilarranz and J. J. Rodriguez: Activated carbon from grape seeds upon chemical activation with phosphoric acid: Application to the adsorption of diuron from water. Chem. Eng. J., 203, 348-356 (2012).

Belaid, K.D., S. Kacha, M. Kameche and Z. Derriche : Adsorption kinetics of some textile dyes onto granular activated carbon. J. Environ. Chem. Eng., 1, 496-503 (2013).

Benadjemia, M., L. Millière, L. Reinert, N. Benderdouche and L. Duclaux: Preparation, characterization and methylene blue adsorption of phosphoric acid activated carbons from globe artichoke leaves. Fuel Process. Technol., 92, 1203-1212 (2011).

Bestani, B., N. Benderdouche, B. Benstaali, M. Belhakem and A. Addou: Methylene blue and iodine adsorption onto an activated desert plant. Bioresour. Technol., 99, 8441-8444 (2008).

BIS: Determination of decolorizing power of carbon, BIS, IS: 877, pp. 910 (1997).

Cherifi, H., B. Fatiha and H. Salah: Kinetic studies on the adsorption of methylene blue onto vegetal fibre activated carbons. Appl. Surf. Sci., 282, 52-59 (2013).

Corcho-Corral, B., M. Olivares-Marín, C. Fernández-González, V. Gómez-Serrano and A. Macías-García: Preparation and textural characterisation of activated carbon from vine shoots (Vitis vinifera) by $\mathrm{H}_{3} \mathrm{PO}_{4}$ - Chemical activation. Appl. Surf. Sci., 252, 5961-5966 (2006).

Dias Joana, M., C.M. Maria, A. Ferraz, M. F. Almeida, J.R. Utrilla and M.S. Polo: Waste materials for activated carbon preparation and its use in aqueous-phase treatment: A review. J. Environ. Manage., 85, 833-846 (2007).

Hameed, B. H., A. T. M. Din and A. L. Ahmad : Adsorption of methylene blue onto bamboo-based activated carbon: Kinetics and equilibrium studies. J. Hazard. Mater., 141, 819-825 (2007).

Hameed, B. H. and A. A. Ahmad : Batch adsorption of methylene blue from aqueous solution by garlic peel, an agricultural waste biomass. J. Hazard. Mater., 164, 870-875 (2009).

Heschel, W. and E. Klose : On the suitability of agricultural by-products for the manufacture of granular activated carbon. Fuel, 74, 17861791 (1995).

Ismaiel, A.A., M.K Aroua and R. Yusoff : Palm shell activated carbon impregnated with task-specific ionic-liquids as a novel adsorbent for the removal of mercury from contaminated water. Chem. Eng. J., 225, 306-314 (2013).

lyer. P.B., K. Sujatha and K. Rajmohan : Comparison of synthetic dyes decolourisation by Ganoderma sp. using immobilized enzyme. J. Environ. Biol., 37, 1507-1514 (2016).

Kannan, N. and M.M. Sundaram: Kinetics and mechanism of removal of methylene blue by adsorption on various carbons-a comparative study. Dyes Pigm., 51, 25-40 (2001).

Malik, P.K. : Dye removal from wastewater using activated carbon developed from sawdust : Adsorption equilibrium and kinetics. J. Hazard. Mater., 113, 81-88 (2004).

Malik. R., D.S. Ramteke and S.R.Wate: Physico-chemical and surface characterisation of adsorbent prepared from groundnut shell by $\mathrm{ZnCl}_{2}$ activation and its ability to adsorb colour. Indian J.Chem. Technol., 13, 319-326 (2006).

Ozdemir, I.S., M. Şahin, R. Orhan and M. Erdem : Preparation and 
characterization of activated carbon from grape stalk by zinc chloride activation. Fuel Process. Technol., 125, 200-206 (2014).

Özer, D., G. Dursun and A. Özer : Methylene blue adsorption from aqueous solution by dehydrated peanut hull. J. Hazard. Mater., 144, 171-179 (2007).

Prahas, D., Y. Kartika, N. Indraswati and S. Ismadji: Activated carbon from jackfruit peel waste by $\mathrm{H}_{3} \mathrm{PO}_{4}$ chemical activation: Pore structure and surface chemistry characterization. Chem. Eng. J., $140,32-42$ (2008).

Reddy, P.M. K., P. Verma and C. Subrahmanyam : Bio-waste derived adsorbent material for methylene blue adsorption. J., Taiwan Inst. Chem. Eng., 58, 500-508 (2016).

Rodríguez-Reinoso, F. and M. Molina-Sabio : Activated carbons from lignocellulosic materials by chemical and/or physical activation : an overview. Carbon, 30, 1111-1118 (1992).

Roopavathi, K. V. and S. Shanthakumar : Adsorption capacity of Curcuma longa for the removal of basic green 1 dye - equilibrium, kinetics and thermodynamic study. J.Environ. Biol., 37, 979-984 (2016).
Sudaryanto, Y., S. B. Hartono, W. Irawaty, H. Hindarso and S. Ismadji : High surface area activated carbon prepared from cassava peel by chemical activation. Bioresour. Technol., 97, 734-739 (2006).

Tan, I. A. W., B. H. Hameed and A. L. Ahmad: Equilibrium and kinetic studies on basic dye adsorption by oil palm fibre activated carbon. Chem. Eng. J., 127, 111-119 (2007).

Tsai, W. T., C. Y. Chang and S. L. Lee: Preparation and characterization of activated carbons from corn cob. Carbon, 35, 1198-1200 (1997).

Tsamba, Alberto J., W. Yang and W. Blasiak: Pyrolysis characteristics and global kinetics of coconut and cashew nut shells. Fuel Process. Technol., 87, 523-530 (2006).

Wang, X.S., Y. Zhou, Y. Jiang and C. Sun: The removal of basic dyes from aqueous solutions using agricultural by-products. J. Hazard. Mater., 157, 374-385(2008).

Zeriouh, A. and L. Belkbir: Thermal decomposition of a Moroccan wood under a nitrogen atmosphere. Thermochim. Acta., 258, 243-248 (1995). 